GLOBAL JOURNAL OF EDUCATIONAL RESEARCH VOL 16, 2017: 75-79

COPYRIGHT@ BACHUDO SCIENCE CO. LTD PRINTED IN NIGERIA. ISSN 1596-6224

www.globaljournalseries.com; Info@globaljournalseries.com

\title{
PERCEIVED INDICATORS IN ENROLMENT OF STUDENTS INTO PHYSICAL EDUCATION SUBJECT IN SECONDARY SCHOOLS IN OBUDU LGA OF CROSS RIVER STATE, NIGERIA
}

\section{BLESSING ANAM AND EMMANUEL AHUEANSEBHOR}

(Received 12, July 2016; Revision Accepted 11, August 2016)

\begin{abstract}
This study investigated the perceived indictors influencing enrolment of students in Physical Education subject in Secondary Schools in Obudu LGA of Cross River State, Nigeria. To achieve this objective, two null hypotheses were formulated and tested in the study. A Sample of $100(6.2 \%)$ of the population was randomly selected using simple random sampling technique. A 15 item questionnaire titled "Students' Enrolment in Physical Education Subject Questionnaire" (SEPESQ) was used to collect data for analysis after being subjected to face validation by three experts in the field of Test and Measurement. The reliability was established through split-half and Pearson Product Moment Correlation Coefficient method with a coefficient value of 0.88 . The Independent $t$-test analysis was adopted in testing the hypotheses at .05 level of significant and 98 degree of freedom. From the result of the analyses, the findings revealed that instructional materials/facilities and personnel qualification have significant influence on students' enrolment in P.E subject. Based on these findings, recommendations were made.
\end{abstract}

KEY WORDS: Indicators, Influence, Enrolment, Physical Education, Obudu, Nigeria.

\section{INTRODUCTION}

Globally, the benefits of Physical Education (P.E) activities have long been recognised and accepted as integral part of education, besides being identified as a subject of its own right. In Nigeria, the introduction of Physical Education subject right from primary school to tertiary institution is a welcome innovation. This is because its activities enhance the psychometric affective and cognitive abilities of the child, thereby making him/her functional and effective contributor to national development afterword; because no nation can grow and develop when her citizens are weaklings. Like other subjects that are cognitive inclined, Physical Education is concerned basically, in developing in the learner, basic skills, techniques abilities and competences that can produce an effective and likely human being who will be able to withstand the change of time, be productive and promote uniqueness in pursuit of unity of human race. (Obikwe, 2002). In the same vein, Alowole, (2000) submitted that the essence of Physical Education is for development of technological, manipulative skills, as well as preparing the students for lifelong activities. According to Ugele (2000) P.E also provide the child with sound mental disposition and a sound body that is able to accommodate the sound

Blessing Anam, Department of Human Kinetics and Health Education, Faculty of Education, University of Calabar, Calabar, Cross River State, Nigeria.

Emmanuel Ahueansebhor, Department of Human Kinetics and Health Education, Faculty of Education, University of Calabar, Calabar, Cross River State, Nigeria. 
mind.

However, the actualisation of these objectives have been inhibited by numerous factors that lowered students' perception in choosing Physical Education as a subject as well as career base courses in higher institutions. According to Dumwen's (2001) view, students' poor foundation, gender interest, parental choices, parental educational status, inadequate teaching facilities, lack of interest, space availability, lack of motivation on the students and teachers and poor materials are factors that have lowered students' enrolment in the choice of physical education. Inyang (1999) described instructional facilities to mean are all those things that is used by the instructor and the learner either in isolation or in combination, formally or informally to facilitate the acquisition of knowledge and skills to enhance involvement in the academic activities, and furthered that instructional messages can only be meaningful if it is utilized adequately, according to the learners' field of study. In a research work conducted by Omini (2002) on the effect of instructional material/facilities on students' disposition towards Physical Education in secondary schools, using Expo-facto as the research design, random sampling as the sampling technique, Pearson Product Moment Correlation as the statistical instrument, with a sample of three hundred (300) students at .05 level of significant, found out that availability of space and recommended textbooks are vital tools that can enhance students' disposition to Physical Education subject. Kleges (2002) noted that, what affects individual interest to Physical Education subject is the availability and utilization of facilities that will enhance their skills level. Also Akintade (2001) study revealed that the instructional facilities enable the learner to feel comfortable in a learning environment thereby making the leaner to be effective in participating in class room activities.

According to Adegoke (2000) another perceived factor influencing students' choice of P.E as examination subject is personnel, stating that no man gives what he does not have. It is the abilities, skill, techniques exhibited by a teacher or other personnel that will influence the administration of others to be enrolled in Physical Education subject. However, personnel have often been looked at as the number one factor in any organization, especially in the teaching profession that can make or mar the organizational goals. Nevertheless, the issue of personnel has been a problem over the years in the teaching of P.E subjects in schools, even up to the higher institutions, if not outright unqualified, it may be unskilled teachers employed, making the problem more compounding. Physical education subject from which its activities evolve into sports programmes required adequate trained and experienced manpower, equipped with necessary skills for the successful implementation of the development of the programme (Haruna, 2013). In the same vein, Bucher (2005) asserted that a valuable service is rendered by qualified physical educator who administers sports programmes in schools, colleges and other agencies, whenever they exist. It is in this vein, and after observations by the researchers on the low enrolment of students in P.E subject in some LGAs in the State, that the researchers intend carrying out this research work, to determine whether the reviewed variables (instructional materials/facilities and personnel qualification) influenced students enrolment in P.E subject in secondary schools in Obudu LGA of Cross River State, Nigeria.

\section{Purpose of the study}

The study was carried out to investigate the perceived indicators that influenced enrolment of students in physical education subject in secondary schools' in Obudu L G A of Cross River State in the areas of instructional materials/facilities and personnel qualification.

\section{Statement of hypotheses}

The following hypotheses were tested in the study at .05 level of significance.

1. Instructional materials/facilities do not significantly influence students' enrolment in Physical Education subject.

2. Personnel qualification does not significantly influence students' enrolment in Physical Education subject.

\section{METHODOLOGY}

The research design adopted for the study is survey design. The population of the study consisted of all Senior Secondary Three (SSIII) students comprising of 1,604 students in the 14 Secondary Schools in Obudu Local Government Area.(State Secondary Education Board, 2016).The sample for the study was 100respondents $(6.2 \%)$ of the population as presented on table 1. Simple random technique was used in the selection of the sample. The 
instrument used for data collection was a 15 item questionnaire titled 'Students' Enrolment in Physical Education Subject Questionnaire" (SEPESQ). The questionnaire was constructed on a four point scale options of Strongly Agree (SA), Agree (A), Disagree (D) and Strongly Disagree (SD). Face validation of the instrument was carried out by three experts in the Department of Human Kinetics and Health Education, and the reliability was established using Split-half method and P-r which yielded a correlation coefficient of 0.88. The statistical tool employed for the analysis of the data was Population t-test analysis at .05 level of significance.

TABLE 1: Sample Distribution of Respondents

\begin{tabular}{llll}
\hline S $n$ & School & Population & Sample (6.2\%) \\
\hline 1 & A & 201 & 13 \\
2 & B & 184 & 11 \\
3 & C & 213 & 13 \\
4 & D & 175 & 11 \\
5 & E & 222 & 14 \\
6 & F & 206 & 13 \\
7 & G & 193 & 12 \\
8 & H & 210 & 13 \\
& Total & 1604 & 100 \\
\hline
\end{tabular}

\section{RESULTS}

The results of the analysis are presented on tables $2 \& 3$.

\section{Hypothesis 1}

Instructional materials/facilities do not significantly influence students' enrolment in Physical Education subject.

TABLE 2: Population -test analysis of the influence of instructional materials/facilities on students' enrolment in physical education subject

\begin{tabular}{|c|c|c|c|c|c|}
\hline Variables & $\mathbf{N}$ & $X$ & $\mu$ & SD & t-cal \\
\hline \multirow[t]{2}{*}{$\begin{array}{l}\text { influence of instructional materials/facilities } \\
\text { students' enrolment in physical education subject }\end{array}$} & & & & & \\
\hline & 100 & 19.53 & 17.5 & 4.42 & $4.59^{*}$ \\
\hline
\end{tabular}

The result from table 2 showed that the calculated t-value of 4.59 is greater than the critical $t-$ value of 1.656 at .05 level of significant with 98 degree of freedom. Thus the null hypothesis was rejected, while the alternate hypothesis was accepted. This means that there is a significant influence of instructional materials/facilities on students' enrolment of
Physical Education subject in secondary schools in Obudu LGA of Cross River State, Nigeria.

\section{Hypothesis 2}

Personnel qualification does not significantly influence students' enrolment in Physical Education subject. 
TABLE 3: Population t-test analysis of personnel qualification on students' enrolment in physical education subject

\section{Variables}

$\mathbf{N}$

$\mathbf{X}$

$\mu \quad$ SD

t-cal

Influence of personnel qualification on students'

enrolment in physical education subject

$100 \quad 23.68$

20.0

$4.87 \quad 7.56^{\star}$

$$
\mathrm{P}<0.5, \mathrm{df}=98, \text { critical } \mathrm{t}=1.656
$$

The result from table 3 showed that at .05 level of significant, with 98degree of freedom, the critical t-value which is 1.656 is less than the calculated t-value of 7.56. With this result the null hypothesis was rejected, while the alternate hypothesis was accepted. This implies that personnel qualification significantly influenced students' enrolment in Physical Education subject in secondary schools in Obudu LGA of Cross River State, Nigeria.

\section{DISCUSSION OF FINDINGS}

The finding of the first hypothesis revealed that there is a positive influence of instructional materials/facilities on the students' enrolment in Physical Education subject in secondary schools in Obudu LGA of Cross River State, Nigeria. This is on the fact that the cal-t of 4.59 is greater than the critical-t which is 1.656 , based on this result, the null hypothesis was rejected. To this end, Kleges (2002) stated that what affects individual interest to Physical Education subject is the availability and utilization of facilities that will enhance their skills level. Also the finding of this study agrees with that of Akintade (2001) which stated that the instructional facilities enable the learner to feel comfortable in a learning environment thereby making the leaner to be effective in participating in class room activities. This implies that the availability and utilization of PE instructional materials/facilities (quality text books, etc,/playing space, basketball court, etc,) will motivate students' high level enrolment of the subject.

The finding from hypothesis two also revealed that there is a positive influence of personnel qualification on the students' enrolment of P.E. subject in secondary schools in Obudu LGA of Cross River State, Nigeria. This is on the fact that the cal-t 7.56 is greater than the critical-t which is 1.656, which causes the rejection of the null hypothesis. This finding is in line with Adegoke (2000) who asserted that no man gives what he does not have. It is the abilities, skill, techniques exhibited by a teacher or other personnel that will influence the administration of others to be enrolled in Physical Education subject. In the same vein, Bucher (2005) asserted that a valuable service is rendered by qualified physical educator who administers sports programmes in schools, colleges and other agencies, whenever they exist.

\section{CONCLUSION}

Based on the findings of the study, the following conclusions were drawn

i. Instructional materials / facilities significantly influenced students' enrolment in Physical Education subject in secondary schools in Obudu LGA of Cross River State, Nigeria.

ii. Personnel qualification significantly influenced students' enrolment in Physical Education subject in secondary schools in Obudu LGA of Cross River State, Nigeria.

\section{RECOMMENDATIONS}

Based on the findings of the study, the following recommendations are made:-

i Government could take sole responsibility of supply and procurement of necessary instructional materials and facilities and ensure high maintenance culture by the administrators respectively.

ii Ministry of education/other educational stakeholders among their criteria, should only approve schools that have enough space and other sports facilities that can cater for the students' practical 
classes, as these will also captivate or motivate their interest towards the subject.

iii Employment of Physical Education teachers must not only be based on qualification but also, acquired knowledge and skilled teachers should be of added advantage (i.e teachers with practical experience) for effective delivery of the subject.

iv Government on their part should organise regular training and retraining programmes for the P.E teachers for updates and efficient teaching of the subject.

v. Evenly distribution of P.E teachers should be ensured to avoid use of novice (i.e the unqualified and the unskilled).

\section{REFERENCES}

Adegoke, U. C., 2000. Physical education handbook for teachers' colleges in Nigeria. Unpublished paper, Ogun State University, Ago - Iwoye.

Akintade, J. M., 2001. Instructional facilities in teaching of physical education in Nigeria schools. Lagos: Uwinting Printing Press.

Alowole, C. H., 2000. Observed role of institutional facilities in Nigeria educational system. Ibadan: University of Ibadan Press.

Bucher, C. A., 2005. Foundation of physical education. St. Louis: The C. V. Mosby company.
Duwen, M. I., 2001. Effect of teaching methods and students' sport performance in primary schools. Akwa lbom: Fielders Publishers.

Haruna, F. R., 2013. Achieving management objectives in Polytechnics, Colleges of Education and Colleges of Technology in Nigeria. Paper presented at the National Seminar/Workshop for Polytechnic Coaches and Chairmen of Sports Committees held at Federal Polytechnic, Bida.

Inyang, A., 1999. Instructional facilities and teachers' qualification on teaching performance in secondary schools in Uyo Local Government Area. Unpublished Research Project.

Kleges, C. Y., 2000. Health science and the young child. New York: Harper and Row Publishers.

Obikwe, G., 2002. Effects of space in student sport performance. A publication in Nigeria; Journal in Physical Education. 26, $908-923$.

Omini. J. B., 2002. Relevance of class size on teacher commitment to students performance. Ikom: Ofem Press.

Ugele, D. O., 2000. Motivation to Learn from theory to practice. Lagos: Odey Publishers. 